\title{
Understanding The Typical Vacations Of U.S. Southern Travelers
}

\author{
William W. Hill, II, Ph.D., Mississippi State University, USA
}

\begin{abstract}
ABTRACT
This paper investigates important factors associated with vacation decisions made for typical vacations by U.S. southern travelers, an area given minimal focus in the marketing tourism literature. The paper effectively identifies key vacation influences to leisure travel which include distance, group size, vacation length, lead time, education level, income level, and age. Additionally, the paper identifies nine unique types of southern vacation travelers using a cluster analysis approach. Ultimately, the paper offers a richer understanding of the pertinent factors influencing vacation decisions_-particularly for individuals in the U.S. Southern region.
\end{abstract}

Keywords: Tourism; Travel; Vacations; Decisions

\section{INTRODUCTION}

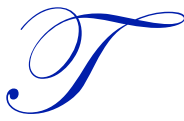

he vacation experience is a central part of the American culture. The benefits are numerouswonderful lifelong memories, the opportunity to connect with family and friends, rest and relaxation, adventures for the soul, and more. Yet, the positives are not just in the enrichment of the individual. The "business of tourism" is substantial, and the U.S. and world economies benefit in a remarkable way. According to the U.S. Travel Association statistics, direct spending on leisure travel in the U.S. exceeds $\$ 640$ billion a year, providing over $\$ 96$ billion in tax revenue. Leisure travel annually creates almost 6 million jobs in the United States (U.S Travel Association, 2014). Internationally, U.S. travelers spend over $\$ 100$ billion a year on leisure vacations (TI Outreach: Outbound Overview, 2013). Thus, the ramifications of vacation travel in the United States and abroad are quite large, giving credence to a greater understanding of leisure travel, and its influencing factors. The implications of studies in this area are also high. They provide value to marketing practitioners who seek revenue maximization through tourism, and they offer a greater understanding to marketing academics who seek knowledge about the leisure vacation phenomenon in the U.S. culture.

This paper examines leisure travel in the southern U.S. - specifically, vacationers from central Mississippi and Alabama. Indeed there is a rich history with the southern vacation traveler. Despite being located in a region with historically lower disposable incomes (Dzombak, 2014), and a decreased international travel history (Auletta, 2011), southern vacationers for generations have retreated to the Appalachian Mountains of Tennessee and North Carolina, to the Ozarks of Missouri, to the beaches on the Gulf Coast panhandle (i.e., the Redneck Riviera), to the ultimate family experience at Walt Disney World in Orlando Florida, and more. Higher-income southern travelers historically vacation in the same places, but they also find refuge in upscale alternatives like the old Florida themed "Seaside" resort along the Gulf Coast, high-end resorts of the barrier islands of South Carolina and Georgia, and in elite locations in Europe. (Griffin, Hargis, \& Wilson, 2012). Indeed, southerners do fly, and in the summer of 2015, Mississippi and Alabama travelers flew most often to California, Florida, Texas, New York, Colorado, and Tennessee (Wells \& Fahey, 2015). Thus, there is much to learn about the southern traveler.

In that light, this paper examines factors that relate to U.S. domestic leisure travelers-targeting vacationers in the central Mississippi-Alabama United States region. Significant associations are identified between key travel factors. Ultimately, typical vacation types are identified through cluster analysis, and conclusions are presented. 


\section{KEY INFLUENCES FOR VACATION DECISIONS}

This papers examines vacation choices relative to two general areas: (1) the vacation travel factors that are relevant to the travel boundaries of the individual, identified as vacation style determinants, and to (2) specific traits about the vacationer that influence the vacation choices made, identified as individual travel factors. The rationale for these areas is discussed next.

\section{Vacation Style Determinants}

Vacation style determinants are travel considerations that are influential to vacation decisions based on the travel boundaries of the individual. These characteristics about a vacation would expect to have varying degrees of appeal and/or resistance, and varying degrees of freedoms and/or constraints, thus helping frame the final vacation decisions made. These possible factors are endless, but for this study, the examined variables are distance, vacation length, group size, and lead time. These factors are discussed next.

Travel distance is suggested to be impactful in segmenting vacationers since some vacationers will prefer the escape and discovery of places far-away, while others will choose the convenience of destinations closer to home. Vacation travel length offers a similar dichotomy in that many will seek an extended getaway to allow more time to relax and to experience more activities while other travelers will be comfortable returning home more quickly. With travel group size, travel preferences are also evident in that traveling with a larger group means more entertainment to some, yet more inconvenience to others. With lead time, some vacationers may like to plan or they have the luxury to plan, and they will "lock in" more activities that may not be available later (i.e., buying tickets to a Broadway play, making reservations for an ideal flight time), thus making more and different options possible to the leisure vacationer. Conversely, non-planners may not be afforded the time to plan or they simply may prefer not to plan. For the latter, it is possible they enjoy the flexibility of "spur of the moment" activities. Planning feels like work. Non-planners are more limited to the vacation options available, but they may have the time to discover activities not considered by the planner.

\section{Individual Travel Factors}

Individual travel factors are specific traits about the vacationer that seem to influence the vacation choices made. These traits could be characterized as demographics about the individual that are associated with vacation decisions. In this study, the individual travel factors proposed are education level, income, and age. These factors are discussed next.

Education level is offered as a key variable, for instance, because higher-educated travelers may seek stimulating vacations that offer more educational value (i.e., historical tours, nature hiking, foreign travel). For income, higherincome travelers may choose vacations of more expense, not only because of the personal enjoyment of a luxury vacation, but also because travel costs are less of an inhibitor. Finally, the age of the vacationer is proposed to have influence on vacation decisions made because travel interests are believed to change with age. Older vacationers may be inclined to enjoy relaxation, good conversation, and great dining experiences. Indeed, it also makes sense that older travelers may be attracted to making memories through family gatherings (i.e., weddings, reunions, anniversaries). Younger travelers would expect to enjoy recreational activities like swimming, golfing, hiking, and thrill-seeking. Younger travelers may also participate in bolder adventures because they have not experienced those journeys before.

\section{METHODOLOGY}

The methodology for this study consisted of a survey and sample collection phase targeting respondents in central Mississippi-Alabama region. The survey asked respondents to identify his/her "typical vacation", and based on that choice, respondents answered questions relating to the identified typical vacation. A summary of the overall methodology is addressed next. 


\section{Survey and Sample Collection}

This data collection process began with the formulation of the study design, development of a survey instrument, and approval of the study by the IRB. Using a convenience sample approach, data was collected through a webbased survey (surveymonkey.com). Undergraduate and graduate business students, their friends, and their families voluntarily participated as respondents in the study. The data was downloaded from the web-based survey platform into an EXCEL spreadsheet. Ultimately, the data was exported from EXCEL into SPSS for statistical analyses.

The data source consisted of 908 inquiries from several regions of the country of which 47 were eliminated due to missing values, key punching errors in the data, etc., leaving 861 inquiries. Since this study focused on respondents from the Mississippi-Alabama region, to be discussed next, the final sample was reduced to 487 inquiries.

\section{Target Respondent}

The target sample consists of respondents from the Mississippi-Alabama region. Since a person's home of residence may dictate vacation options available to a leisure traveler, and since cultural and generational travel traditions would expect to be common by region, the sample was focused simply on respondents living in central MississippiAlabama. As such, residents from the "heart of Mississippi and Alabama" are the focus of this paper. Figure 1 displays the respondent region represented in the dataset.

Figure 1. Respondent Region*

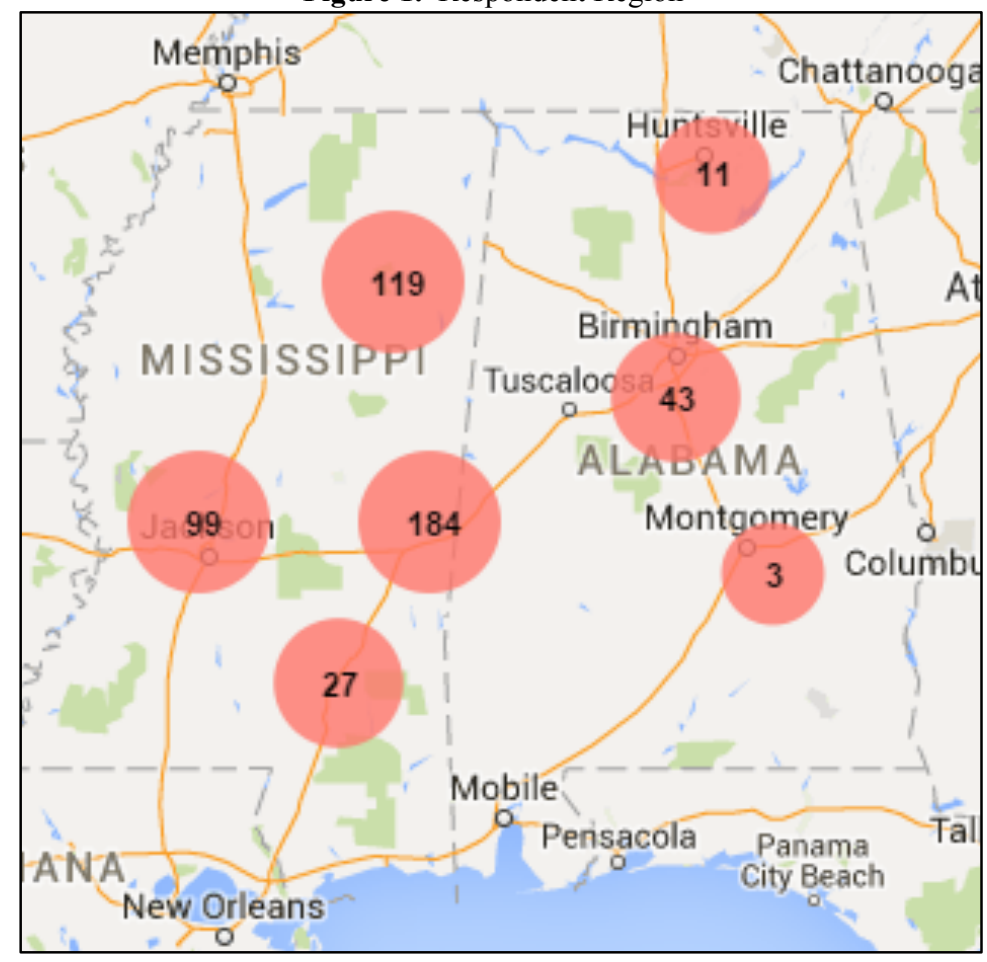

*Easymapmaker.com

\section{Correlation Matrix and Cluster Analysis}

A correlation between the cluster variables was performed in SPSS. The correlation matrix was structured highlighting the direction and significance of the correlations between the cluster variables. For the cluster analysis, following previous research techniques (Hill, Beatty, and Walsh, 2013; Henning-Thurau et al, 2004), a hierarchical cluster analysis, followed by a k-means analysis was employed. In the analysis, cluster distances were calculated 
using the Euclidean distance measure. For the aggregated clusters, Ward's procedure was used to calculate distances. Finally, the elbow criterion was used to determine the total number of clusters groups in the assessment. Once the cluster groups were identified and tagged in SPSS, descriptive data for each cluster group was formulated for review and interpretation.

\section{FINDINGS}

The findings for this study are organized into two general areas: overall results and relationships, and vacation traveler types. The overall results and relationships are detailed next.

\section{Overall Results}

Table 1 displays the frequency distribution for the cluster variables and categorical descriptors variables. Table 1 offers some interesting facts about the respondent vacationers from the central Mississippi-Alabama region. Relative to the variables pertaining to vacation design, $78.9 \%$ of respondents reported they typically travel less than 600 miles from home on a typical vacation. For travel group size, $2.7 \%$ of respondents reported vacationing alone. The most common travel group size reported was 3 to 4 people (37.2\%). For typical vacation length, $76 \%$ of vacationers indicated 3 and 6 days is typical, with only $3.3 \%$ of respondents reporting vacations lasting 9 days or longer. In terms of the typical planning time, $77.3 \%$ of vacationers reported the lead time in planning a vacation to be between 2 weeks and 6 months. The most common lead time was 3 to 6 months (37.1\%), with 7.4\% reporting "last minute" vacations (i.e., less than two weeks planning time).

Relative to individual demographic variables, $85.4 \%$ of respondents had an education level from "some college" to a Master's degree, with the most common level of education reported as a Bachelor's degree (32.8\%). For typical income level, the most typical income range was between $\$ 40,000$ and $\$ 119,999(50.1 \%)$ a year, with $30 \%$ making less than $\$ 40,000$, and $19.9 \%$ making more than $\$ 120,000$. The most common age range of respondents was from 25 to 31 years olds $(24.1 \%)$, with $81.1 \%$ ranging in age from 18 to 52 . Roughly three percent $(3.1 \%)$ of the respondents were 67 or older.

The vacation type choices identified as representative of typical vacations were tropical (42.5\%), outdoors (17.7\%), family $(19.1 \%)$, and big event \& big city $(14.8 \%)$. A tropical vacation represented beach vacations, with a small number reporting tropical cruises. Outdoor vacations, not surprisingly, was represented by hiking, camping, hunting, and fishing trips. Family vacations included vacations that involved visiting family members, such as holiday visits, annual family vacations, and family reunions. Big event \& big city vacations captured trips to ballparks, festivals, shopping weekends, concerts, etc. that usually involved going to a large event and/or a large metropolitan area.

The most common vacation season reported was April through June (46.6\%) with July to September being the second most common vacation season (35.9\%). Relative to vacation companions, very few respondents reported vacationing alone $(2.1 \%)$. The most common travel groups were groups traveling as a couple with spouse/partner (24.1\%), and groups traveling with spouse/partner and children (28.2\%). The most common lodging options were hotel/motel (41.3\%), condominium (27.5\%), and staying with family or friends (15.4\%). Relative to travel modes, about $92.2 \%$ of travelers identified use of a car for typical vacations; this was followed by airline (30.4\%), rental car $(16.4 \%)$, taxi $(8.2 \%)$, cruise $(5.3 \%)$, and subway $(5.3 \%)$.

The final numbers shown in Table 1 are the responses to a series of "yes/no" questions about vacation travel. The strongest "yes" response observed was for the level of respondents using the Internet to plan online (82.1\%) and make reservations online $(76.2 \%)$ for their vacation. Additionally, these questions highlighted that $53.1 \%$ of respondents have traveled internationally, $9.9 \%$ travel with a pet, $17 \%$ are members of AAA, $3.1 \%$ travel with a tour, and $3.9 \%$ use a travel agent. 
Table 1. Descriptive Characteristics

\begin{tabular}{|c|c|c|c|c|c|}
\hline Characteristics & Frequency & Percent & Characteristics & Frequency & Percent \\
\hline Distance (miles); $\mathrm{n}=481$ & & & Residence Status; $n=487$ & & \\
\hline 200 or less & 71 & 14.8 & Single; living with parents or family & 53 & 10.9 \\
\hline 201 to 400 & 223 & 46.4 & Single; living alone & 58 & 11.9 \\
\hline 401 to 600 & 85 & 17.7 & Single; living with my children & 30 & 6.2 \\
\hline 601 to 800 & 40 & 8.3 & Married/partner & 167 & 34.3 \\
\hline 801 to 1000 & 29 & 6.0 & $\begin{array}{l}\text { Married/partner; living with my } \\
\text { children }\end{array}$ & 164 & 33.7 \\
\hline 1000 or greater & 33 & 6.8 & Other & 15 & 3.0 \\
\hline Group Size (number); $n=487$ & & & Vacation Type; $n=487$ & & \\
\hline 1 person & 13 & 2.7 & Tropical (Beach) & 207 & 42.5 \\
\hline 2 people & 122 & 25.1 & Family & 93 & 19.1 \\
\hline 3 to 4 people & 181 & 37.2 & Outdoor \& Recreational & 86 & 17.7 \\
\hline 5 to 6 people & 105 & 21.6 & Big Event \& Big City & 72 & 14.8 \\
\hline 7 or greater & 66 & 13.6 & Other & 29 & 6.0 \\
\hline Vacation Length (days);n=487 & & & Vacation Season; $\mathrm{n}=487$ & & \\
\hline 1 to 2 nights & 55 & 11.3 & January-March & 31 & 6.4 \\
\hline 3 to 4 nights & 224 & 46.0 & April-June & 227 & 46.6 \\
\hline 5 to 6 nights & 146 & 30.0 & July-September & 175 & 35.9 \\
\hline 7 to 8 nights & 46 & 9.4 & October-December & 54 & 11.1 \\
\hline 9 or greater & 16 & 3.3 & Vacation Companions; $\mathrm{n}=486$ & & \\
\hline Lead Time (months); $n=485$ & & & Alone & 10 & 2.1 \\
\hline Less than 2 weeks & 36 & 7.4 & With friends & 51 & 12.6 \\
\hline$>2$ weeks to 1 month & 80 & 16.5 & My spouse/partner & 117 & 24.1 \\
\hline$>1$ months to 3 months & 180 & 37.1 & My spouse/partner \& children & 137 & 28.2 \\
\hline$>3$ months to 6 months & 115 & 23.7 & Family and friends & 105 & 21.6 \\
\hline$>6$ months to 9 months & 37 & 7.6 & Family and ext. family & 44 & 9.1 \\
\hline$>9$ months to 12 months & 32 & 6.6 & Family, ext. family \& friends & 11 & 2.3 \\
\hline 12 months or greater & 5 & 1.0 & Other & 11 & 2.3 \\
\hline Education Level (college years); $n=485$ & & & Lodging; $\mathrm{n}=487$ & & \\
\hline Some high school & 6 & 1.4 & Motel/Hotel & 201 & 41.3 \\
\hline High school degree or GED & 39 & 7.4 & Condominium & 135 & 27.5 \\
\hline Some college & 109 & 21.8 & Family or Friends & 75 & 15.4 \\
\hline 2-Year Associate degree & 67 & 12.9 & Rental House & 20 & 4.1 \\
\hline 4-Year Bachelor degree & 145 & 32.8 & Other & 22 & 4.5 \\
\hline Graduate Master's degree & 90 & 17.9 & Travel Modes (\%Yes); $\mathrm{n}=487$ & & \\
\hline Professional or Doctorate & 29 & 5.8 & Car & 449 & 92.2 \\
\hline Income (\$); $\mathrm{n}=477$ & & & Airline & 148 & 30.4 \\
\hline Less than $\$ 40,000$ & 143 & 30.0 & Rental Car & 80 & 16.4 \\
\hline$\$ 40,000$ to $\$ 119,999$ & 239 & 50.1 & Taxi & 40 & 8.2 \\
\hline$\$ 120,000$ or greater & 95 & 19.9 & Cruise & 26 & 5.3 \\
\hline Age (years); $\mathrm{n}=486$ & & & Subway & 26 & 5.3 \\
\hline $18-24$ & 73 & 15.0 & Train & 14 & 2.9 \\
\hline $25-31$ & 117 & 24.1 & Bus & 11 & 2.3 \\
\hline $32-38$ & 65 & 13.4 & RV & 8 & 1.6 \\
\hline $39-45$ & 58 & 11.9 & Yacht & 2 & 0.4 \\
\hline $46-52$ & 81 & 16.7 & \multirow{4}{*}{ 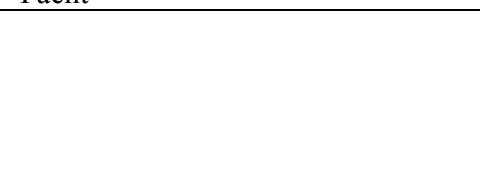 } & & \\
\hline $53-59$ & 48 & 9.9 & & & \\
\hline $60-66$ & 29 & 6.0 & & & \\
\hline 67 or greater & 15 & 3.1 & & & \\
\hline
\end{tabular}

(Table 1 continued on next page) 
(Table 1 continued)

\begin{tabular}{l|r|l|l|r|r}
\hline \multicolumn{1}{c|}{ Characteristics } & Frequency & Percent & \multicolumn{1}{c}{ Characteristics } & Frequency & Percent \\
\hline Working Status & & & Questions (\%Yes) & & \\
\hline Employed (full-time) & 332 & 68.3 & Typically travels with tour & 15 & 3.1 \\
\hline Employed (part-time) & 38 & 7.8 & Typically uses travel agent & 19 & 3.9 \\
\hline Self-employed & 20 & 4.1 & Typically plans trip online & 400 & 82.1 \\
\hline Unemployed & 7 & 1.4 & Typically books trip online & 371 & 76.2 \\
\hline Stay at home worker & 10 & 2.1 & Typically travels with a pet & 48 & 9.9 \\
\hline Student & 4 & 0.8 & Smokers in travel party & 90 & 18.5 \\
\hline Retired & 59 & 12.1 & Member of AAA & 83 & 17.0 \\
\hline Employed (full-time) & 16 & 3.3 & Traveled internationally & 260 & 53.1 \\
\hline
\end{tabular}

In Table 2, a correlation matrix for the cluster variables is provided. A number of significant associations can be stated. The strongest associations with distance are the direct associations with vacation length $(\beta=.471, p<.01)$ and lead time $(\beta=.259, \mathrm{p}<.01)$. Both findings are reasonable since vacations farther from home tend to be longer vacations requiring more travel time, and vacations farther from home may be less familiar to the traveler, thus requiring more time to prepare. The only inverse association for distance is with group size $(\beta=-.100, p<.05)$. This finding also makes sense in that it is easier and less costly to travel with a smaller group on greater distance trips. The strongest association with group size is the direct association with lead time $(\beta=.244, p<.01)$ and the inverse association with education level $(\beta=-.147, \mathrm{p}<.01)$. Again, large travel groups probably need more time to plan. As for larger vacation groups being less educated, it could be that less educated groups tend to congregate together to make the trip more affordable, although a relationship between group size and income level is not supported. Another explanation may be that less educated leisure travelers show preference to larger groups, placing more value on family and social gatherings. The strongest associations with vacation length are the direct associations with lead time $(\beta=.408, p<.01)$ and income level $(\beta=.241, \mathrm{p}<.01)$. There are good explanations for each. It is not surprising longer vacations require more planning and therefore earlier planning, and longer vacations clearly require more disposable income. Lead time also shows a direct relationship with income level $(\beta=.190, p<.01)$. The lead time and income relationship follows because income can be linked with longer vacations. With education level, the strongest direct association is with income level $(\beta=.339, \mathrm{p}<.01)$. This supports the recognized belief that the greater the education level, the greater the likelihood of a higher income level. Note that these variables can have multicollinearity tendencies, but not in this study, suggesting both education level and income level offer unique variance explanations in the findings. Finally, the strongest associations with age are the direct associations with income level $(\beta=.391, \mathrm{p}<.01)$ and distance $(\beta=.097, \mathrm{p}<.05)$, and the inverse association with group size $(\beta=-$ $.112, \mathrm{p}<.05)$. There are good reasons for each of these relationships. Age and income would expect to be directly related since income generally increases over the course of a working career. As for age and distance traveled, older leisure travelers would to expect to take vacationers farther from home because of the time they are afforded with retirement, the confidence they have with age in going farther from home, and perhaps the greater the urge to take "the bucket list" vacations farther from home. Finally here, relative to age and group size, older travelers would expect to travel in smaller group sizes because of the "empty nest" possibilities evident with age.

Table 2. Correlation Matrix

\begin{tabular}{|c|c|c|c|c|c|c|c|}
\hline & 1 & 2 & 3 & 4 & 5 & 6 & 7 \\
\hline Distance (miles) & --- & & & & & & \\
\hline Group Size (number) & $-.100^{*}$ & --- & & & & & \\
\hline Lead time (months) & $.259^{* *}$ & $.244^{* *}$ & $.408^{* *}$ & --- & & & \\
\hline Education Level (college years) & $.098^{*}$ & $-.147^{* *}$ & .080 & .015 & --- & & \\
\hline Income Level ( $\$$, thousands) & $.110^{*}$ & .013 & $.241^{* *}$ & $.190^{* *}$ & $.339^{* *}$ & --- & \\
\hline
\end{tabular}

$* \quad p<.05$ (Correlation is significant at the 0.05 level)

$* * p<.01$ (Correlation is significant at the 0.01 level) 


\section{Interpretation and Description of Cluster Segments}

The nine-cluster solutions are named: "Homeward Bound Youngsters", "All Seasons Recreational Vacationers", "Youthful Strategic Explorers", "Young Family Homers", "Mass Family Beach Assemblers", "Educated Global Excursionists", "Upscale Family Beachers", "Seasoned Old School Travelers", and "Last-Minute Jaunting Dependents. The descriptive data for each group is shown in Table 3, and each group is discussed in the following section.

Cluster one ( $\mathrm{n}=33$ ), categorized as the "Homeward Bound Youngsters" segment, is the youngest segment (age 25). It is a group consisting of single travelers (54.5\%), and single travelers that live independently (33.3\%). These younger travelers make lower in income ( $\$ 36 \mathrm{~K}$ per year) as compared to the other segments. Yet, this group is more educated, consisting of more students (33.3\%), averaging 3.8 years of college experience. As vacationers, this group is typically small ( 2.8 people), travels alone $(9.1 \%)$ or with friends $(30.3 \%)$, is more likely to travel to see family (42.4\%), and is more likely to lodge with family $(42.4 \%)$. This group plans at the "last minute" if at all $(.75$ months), and takes shorter length trips (3.6 days). Because this group is typically traveling to family, likely to familiar places, it makes sense this group is less likely to plan a vacation online $(69.7 \%)$ as compared to the other vacations types.

Cluster two ( $\mathrm{n}=28)$, categorized as the "All-Seasons Recreational Vacationers" segment, is a mid-40s travel group that plans very early (9.6 months), and often travels greater distances (958 miles) for longer stays (7.1 days). The groups typically travels with spouse/partner and children (35.7\%) and consists of just over five travel members (5.3). While this group travels to tropical locations like the other travel segments, they often travel to outdoor recreational places (25.0\%), and they vacation all seasons of the year. Not surprisingly, because of the greater distance traveled, and because of the variety of vacations taken, this group generally uses more modes of transportation during vacations.

Cluster three ( $\mathrm{n}=42$ ), categorized as the "Youthful Strategic Explorers" segment, is a young segment (age 26) that is generally more likely to be single, and could even be living with parents/partners. This group is more likely to be in school, and yet makes a good income $(\$ 68 \mathrm{~K})$ comparably between segments for their age. This young travel group tends to travel with friends or with family, and normally consists of about five (5.0) vacationers. Individuals in this travel group plan early (6.9 months), use the Internet to browse (92.9\%) and reserve (90.5\%), and travel more internationally $(59.5 \%)$ than other groups. This groups seems to be industrious based on the early planning of travel, the farther distance traveled (420 miles), and the propensity for vacationing globally.

Cluster four ( $\mathrm{n}=64$ ), categorized as the "Young Family Homers" segment, is a young small (3.2) travel group (age $29)$, that is more likely to be married $(40.6 \%)$, or married with children $(25 \%)$. Individuals in this travel group are more educated (4.6 years), generally travel a shorter distance (310 miles) to the destination, and while they travel to a variety of locations, more typically than the other travel segments, will travel to visit family and lodge with family.

Cluster five ( $\mathrm{n}=25)$, categorized as the "Mass Family Beach Assemblers", is the largest travel group, and consists of younger travelers (31). These vacationers plan very early (7 months), and travel with family, extended family, and friends. As such, it is not surprising that this is a larger travel group (6.9). These vacationers seem to travel to the beach, and more often in the spring and summer. Because these beach travelers seem to plan early, it is not a surprise that these individuals typically plan and reserve online.

Cluster six ( $\mathrm{n}=43)$, categorized as the "Educated Global Excursionists" segment, is a smaller travel group (2.7) in their late 30s (age 39) who have a greater tendency to travel as a spouse/partner couple (39.5\%). Also, this highly educated (5.4 years) vacation group travels to all destinations, and is actually the least likely to travel tropical. This group is the most likely of all the travel groups to travel internationally (78.6\%), and not surprisingly, more often uses additional modes of travel, reserves on the Internet, and are members of AAA.

Cluster seven ( $\mathrm{n}=65$ ), categorized as the "Upscale Family Beachers", is early middle-aged (age 41) travel group, more often higher-educated (4.8 years), higher-incomed $(\$ 121 \mathrm{~K})$, that often travels with nuclear family, immediate 
family, extended family, and friends $(89.3 \%)$. Not surprisingly, this group is typically one of the larger vacation groups (5.5). Moreover, these vacationers more often vacation tropical (64.6\%), and stay in a condominium $(58.5 \%)$. This group vacations $95.4 \%$ of the time from April through September, the highest of any cluster group. Since this group is also one of the highest to use automobiles (98.4\%) and travels, on average, only about 290 miles, it is proposed these leisure travelers enjoy the nearby beaches along the gulf coast.

Cluster eight ( $\mathrm{n}=127)$, categorized as "Seasoned Old School Travelers" is by far the largest cluster group in this analysis. This middle-age to senior group (age 54), is a smaller travel group (3.3), and more typically travels as either spouse/partner only $(37.0 \%)$, or spouse/partner and children $(29.9 \%)$. Although this vacation cluster is the most distinct in the variety of vacation destination choices made, it is the most typical of all the groups to travel to outdoor \& recreational places $(25.2 \%)$. This vacation group is also the most likely to stay in a motel/hotel $(48.8 \%)$, which could suggest the desire for affordable lodging and/or perhaps the desire for staying in familiar motel/hotel brands. This group vacations between April and December $94.5 \%$ of the time, which is more often than compared to the other travel groups.

Cluster nine ( $\mathrm{n}=41$ ), categorized as "Last-Minute Jaunting Dependents", like the "Homeward Bound Youngsters", is the youngest cluster group (age 25). Individuals in this travel group are less educated (0.6 years), and are the most likely to be single and living with parents or family (51.2\%). The group consists of the smallest percentage of fulltime employment of any group (48.8\%). This group of vacationers seems to plan relatively late (1.3 months), travel more often with friends alone $(22.0 \%)$ or with family and friends $(31.7 \%)$, and are the least likely of any travel group to travel with a spouse/partner (7.3\%). This travel group also vacations in a variety of locations, is the most likely to use the automobile (100\%), and is the least likely to use an airline (7.3\%). Not surprisingly, this group, due to the age and dependence level of these vacationers as compared to others, had the lowest percentage of AAA members $(4.9 \%)$.

Table 3. Cluster Findings

\begin{tabular}{|c|c|c|c|c|c|c|c|c|c|}
\hline Clusters & $\begin{array}{c}C-1 \\
(n=33)\end{array}$ & $\begin{array}{c}\mathrm{C}-2 \\
(\mathrm{n}=28)\end{array}$ & $\begin{array}{c}\mathrm{C}-3 \\
(\mathrm{n}=42)\end{array}$ & $\begin{array}{c}\mathrm{C}-4 \\
(\mathrm{n}=64)\end{array}$ & $\begin{array}{c}C-5 \\
(n=25)\end{array}$ & $\begin{array}{c}C-6 \\
(n=43)\end{array}$ & $\begin{array}{c}C-7 \\
(n=65)\end{array}$ & $\begin{array}{c}\mathbf{C - 8} \\
(\mathrm{n}=127)\end{array}$ & $\begin{array}{c}C-9 \\
(n=41)\end{array}$ \\
\hline \multicolumn{10}{|l|}{ STEP 1: Cluster Identification Variables } \\
\hline Distance (miles)* & $342^{b}$ & $958^{\mathrm{a}}$ & $420^{b}$ & $310^{b}$ & $348^{\mathrm{b}}$ & $924^{\mathrm{a}}$ & $290^{b}$ & $362^{b}$ & $286^{\mathrm{b}}$ \\
\hline Size of Party (number)* & $2.8^{\mathrm{d}}$ & $5.3^{\mathrm{a}, \mathrm{b}}$ & $5.0^{\mathrm{b}, \mathrm{c}}$ & $3.2^{\mathrm{c}, \mathrm{d}}$ & $6.9^{\mathrm{a}}$ & $2.7^{\mathrm{d}}$ & $5.5^{\mathrm{a}, \mathrm{b}}$ & $3.3^{\mathrm{c}, \mathrm{d}}$ & $4.9^{b, c}$ \\
\hline Length of Stay (days)* & $3.6^{\mathrm{d}, \mathrm{e}}$ & $7.1^{\mathrm{a}}$ & $5.2^{b, c}$ & $3.3^{\mathrm{e}}$ & $5.3^{b}$ & $5.7^{b}$ & $4.8^{\mathrm{b}, \mathrm{c}, \mathrm{d}}$ & $4.0^{\mathrm{c}, \mathrm{d}, \mathrm{e}}$ & $3.5^{\mathrm{d}, \mathrm{e}}$ \\
\hline Lead Time (months)* & $0.75^{\mathrm{e}}$ & $9.6^{\mathrm{a}}$ & $6.9^{\mathrm{a}}$ & $2.2^{b, c, d}$ & $7.0^{\mathrm{a}}$ & $3.4^{\mathrm{b}}$ & $3.3^{\mathrm{b}, \mathrm{c}}$ & $1.7^{\mathrm{c}, \mathrm{d}}$ & $1.3^{\mathrm{d}, \mathrm{e}}$ \\
\hline Education Level (college years)* & $3.8^{\mathrm{a}, \mathrm{b}}$ & $1.5^{\mathrm{d}, \mathrm{e}}$ & $2.9^{\mathrm{b}, \mathrm{c}}$ & $4.6^{\mathrm{a}, \mathrm{b}}$ & $0.6^{\mathrm{e}}$ & $5.4^{\mathrm{a}}$ & $4.8^{\mathrm{a}}$ & $1.9^{\mathrm{c}, \mathrm{d}}$ & $0.6^{\mathrm{e}}$ \\
\hline Income Level (thousands)* & $36^{\mathrm{d}, \mathrm{e}}$ & $84^{\mathrm{a}, \mathrm{b}, \mathrm{c}}$ & $68^{b, c}$ & $67^{\mathrm{b}, \mathrm{c}, \mathrm{d}}$ & $56^{\mathrm{c}, \mathrm{d}, \mathrm{e}}$ & $99^{\mathrm{a}, \mathrm{b}}$ & $121^{\mathrm{a}}$ & $81^{\mathrm{a}, \mathrm{b}, \mathrm{c}}$ & $33^{\mathrm{e}}$ \\
\hline Age (years)* & $25^{\mathrm{c}}$ & $44^{\mathrm{b}}$ & $26^{\mathrm{c}}$ & $29^{\mathrm{c}}$ & $31^{\mathrm{c}}$ & $39^{b}$ & $41^{b}$ & $54^{\mathrm{a}}$ & $25^{\mathrm{c}}$ \\
\hline \multicolumn{10}{|l|}{ STEP 2: Descriptor Variables } \\
\hline \multicolumn{10}{|l|}{ Working Status $(p<.05)^{* * * *}$} \\
\hline Employed (full-time) & 51.5 & 57.1 & 64.3 & 71.4 & 72.0 & 76.7 & 86.2 & 68.5 & 48.8 \\
\hline Employed (part-time) & 15.2 & 7.1 & 9.5 & 7.9 & 8.0 & 7.0 & 6.2 & 5.5 & 14.6 \\
\hline Self-employed & 0.0 & 14.3 & 0.0 & 3.2 & 0.0 & 2.3 & 4.6 & 5.5 & 2.4 \\
\hline Unemployed & 0.0 & 7.1 & 0.0 & 0.0 & 0.0 & 0.0 & 0.0 & 1.6 & 7.3 \\
\hline Stay at home worker & 0.0 & 3.6 & 2.4 & 1.6 & 0.0 & 0.0 & 1.5 & 3.9 & 2.4 \\
\hline Student & 33.3 & 10.7 & 23.8 & 15.9 & 20.0 & 14.0 & 1.5 & 1.6 & 24.4 \\
\hline Retired & 0.0 & 0.0 & 0.0 & 0.0 & 0.0 & 0.0 & 0.0 & 11.0 & 0.0 \\
\hline \multicolumn{10}{|l|}{ Vacation Companions $(p<.05)^{x+k}$} \\
\hline Alone & 9.1 & 0.0 & 0.0 & 1.6 & 0.0 & 7.0 & 0.0 & 1.6 & 2.4 \\
\hline With friends & 30.3 & 7.1 & 14.3 & 10.9 & 0.0 & 9.3 & 4.6 & 7.1 & 22.0 \\
\hline My spouse/partner & 12.1 & 10.7 & 19.0 & 32.8 & 8.0 & 39.5 & 6.2 & 37.0 & 7.3 \\
\hline My spouse/partner \& children & 9.1 & 35.7 & 11.9 & 23.4 & 20.0 & 23.3 & 58.5 & 29.9 & 17.1 \\
\hline Family and friends & 33.3 & 25.0 & 38.1 & 21.9 & 36.0 & 16.3 & 15.4 & 13.4 & 31.7 \\
\hline Family and ext. family & 3.0 & 7.1 & 11.9 & 4.7 & 32.0 & 2.3 & 10.8 & 7.1 & 14.6 \\
\hline Family, ext. family \& friends & 0.0 & 3.6 & 2.4 & 1.6 & 0.0 & 2.3 & 4.6 & 1.6 & 2.4 \\
\hline
\end{tabular}




\begin{tabular}{|c|c|c|c|c|c|c|c|c|c|}
\hline \multicolumn{10}{|l|}{ Vacation Type $(\mathrm{p}<.05)^{* *}$} \\
\hline Tropical (Beach) & 36.4 & 7.1 & 54.8 & 46.9 & 56.0 & 9.3 & 64.6 & 40.2 & 48.8 \\
\hline Outdoor \& Recreational & 9.1 & 25.0 & 16.7 & 12.5 & 20.0 & 18.6 & 7.7 & 25.2 & 17.1 \\
\hline Family & 42.4 & 21.4 & 7.1 & 25.0 & 12.0 & 23.3 & 10.8 & 19.7 & 14.6 \\
\hline Big Event \&/or Big City & 12.1 & 28.6 & 14.3 & 14.1 & 8.0 & 27.9 & 13.8 & 9.4 & 19.5 \\
\hline \multicolumn{10}{|l|}{ Lodging $(\mathrm{p}<.05)^{* *}$} \\
\hline Motel/Hotel & 45.5 & 28.6 & 35.7 & 40.6 & 28.0 & 60.5 & 23.1 & 48.8 & 51.2 \\
\hline Resort & 0.0 & 25.0 & 7.1 & 4.7 & 4.0 & 9.3 & 9.2 & 4.7 & 2.4 \\
\hline Condominium & 12.1 & 3.6 & 42.9 & 29.7 & 40.0 & 7.0 & 58.5 & 21.3 & 26.8 \\
\hline Family or Friends & 42.4 & 21.4 & 4.8 & 21.9 & 4.0 & 16.3 & 4.6 & 15.0 & 12.2 \\
\hline \multicolumn{10}{|l|}{ Vacation Season $(\mathrm{p}<.05)^{* *}$} \\
\hline January-March & 15.2 & 25.0 & 4.8 & 0.0 & 8.0 & 7.0 & 3.1 & 5.5 & 7.3 \\
\hline April-June & 36.4 & 35.7 & 52.4 & 53.1 & 60.0 & 46.5 & 52.3 & 39.4 & 51.2 \\
\hline July-September & 33.3 & 21.4 & 38.1 & 39.1 & 32.0 & 30.2 & 43.1 & 38.6 & 34.1 \\
\hline October-December & 15.2 & 17.9 & 4.8 & 7.8 & 0.0 & 16.3 & 1.5 & 16.5 & 7.3 \\
\hline \multicolumn{10}{|l|}{ Travel Modes (\%Yes) } \\
\hline $\operatorname{Car}(\mathrm{p}<.05)^{* *}$ & 90.9 & 71.4 & 97.6 & 93.8 & 92.0 & 72.1 & 98.5 & 94.5 & 100.0 \\
\hline Airline $(\mathrm{p}<.05)^{* *}$ & 24.2 & 60.7 & 35.7 & 23.4 & 24.0 & 83.7 & 23.1 & 22.0 & 7.3 \\
\hline Rental Car $(\mathrm{p}<.05)^{* *}$ & 21.2 & 21.4 & 14.3 & 14.1 & 20.0 & 51.2 & 4.6 & 10.2 & 12.2 \\
\hline $\operatorname{Taxi}(\mathrm{p}<.05)^{* *}$ & 6.1 & 14.3 & 11.9 & 7.8 & 4.0 & 30.2 & 6.2 & 1.6 & 7.3 \\
\hline Cruise $(\mathrm{p}<.05)^{* *}$ & 0.0 & 14.3 & 16.7 & 1.6 & 8.0 & 7.0 & 3.1 & 3.9 & 0.0 \\
\hline Subway $(\mathrm{p}<.05)^{* *}$ & 6.1 & 17.9 & 7.1 & 3.1 & 0.0 & 18.6 & 4.6 & 0.0 & 4.9 \\
\hline $\operatorname{Bus}(\mathrm{p}<.05)^{* *}$ & 3.0 & 14.3 & 0.0 & 1.6 & 0.0 & 0.0 & 0.0 & 1.6 & 4.9 \\
\hline \multicolumn{10}{|l|}{ Questions (\%Yes) } \\
\hline Typically plans trip online $(\mathrm{p}<.05)^{* *}$ & 69.7 & 78.6 & 92.9 & 93.8 & 96.0 & 93.0 & 84.6 & 69.8 & 87.8 \\
\hline Typically books trip online $(\mathrm{p}<.05)^{* *}$ & 75.8 & 78.6 & 90.5 & 84.4 & 88.0 & 90.7 & 70.8 & 66.1 & 68.3 \\
\hline Member of AAA $(\mathrm{p}<.05)^{* *}$ & 6.1 & 17.9 & 7.1 & 18.8 & 12.0 & 23.3 & 23.4 & 23.2 & 4.9 \\
\hline Traveled internationally $(\mathrm{p}<.05)^{* *}$ & 48.5 & 57.1 & 59.5 & 51.6 & 36.0 & 78.6 & 66.2 & 44.7 & 46.3 \\
\hline
\end{tabular}

*Mean contrasts are significant at $\mathrm{p}<.05$ (according to Scheffe test). Values with different superscripts are significantly different from each other; superscripts are such that "a" always represents the highest score. ${ }^{* *}$ Chi-square tests were applied to these relationships ( $<<.05$ ).

\section{CONCLUSIONS}

This paper identifies two new concepts, vacation style determinants and individual travel factors, with a sample of respondents from the central Mississippi-Alabama region, and effectively integrates these elements to determine types of southern leisure vacation travelers. Specifically, the paper is unique in that it targets southern U.S. vacationers, an area given almost no attention in the marketing tourism literature. The paper also effectively reinforces the relevance of key vacation influences to leisure travel, suggesting distance, group size, vacation length, lead time, education level, income level, and age are pertinent factors shaping the vacations people take. Thus, the paper offers the beginning of an understanding of "why we take the vacations we do". Ultimately, a foundation of vacation types have been identified to build on and validate in future studies of this nature with respondents from the central Mississippi-Alabama region and beyond.

Relative to limitations with this paper, the definition of the "typical vacation" was not offered in the survey instrument. This approach made the general assumption that the respondent knew what is meant by the "typical vacation". Moreover, because of the quantitative nature of the study, extensive respondent feedback on the typical vacation was not captured. Thus, future research should concentrate on exploratory studies to refine the "typical vacation" concept. Another limitation to the paper would be the demographics of the respondents were not matched with the demographics of the region (central Mississippi and Alabama). Thus, although the findings are generally representative of many individuals in the region (based on the convenience sample), caution should be given to generalizing the results to everyone in the central Mississippi-Alabama area. Future studies should attempt to match the respondent sample with the typical demographics of the region. 


\section{AUTHOR BIOGRAPHY}

Dr. Hill has over 29 years of experience in the private and public sectors. His research interests include the areas of purchase decision making, personal selling, and tourism. Dr. Hill's consulting experience encompasses work with tourism, small businesses, and the healthcare industry. He is a member of the American Marketing Association and the Society for Marketing Advances. Dr. Hill currently serves as the Division Head of Business and Associate Professor of Marketing for the Mississippi State University Meridian Campus. Email: whill@meridian.msstate.edu

\section{REFERENCES}

Auletta, K. (2011). U.S. Passport Holders By State (MAP). Retrieved November 9, 2015, from http://www.huffingtonpost.com/2011/03/09/post_662_n_833399.html

Central Mississippi-Alabama Respondents. (n.d.). Retrieved December 18, 2015, from http://www.easymapmaker.com/map/cab5a1dbd7311c00c38c4e949662c9ee

Dzombak, D. (2014). Which States' Residents Have the Most Cash to Spend? -- The Motley Fool. Retrieved November 9, 2015, from http://www.fool.com/investing/general/2014/10/05/which-states-residents-have-the-most-cash-to-spend.aspx

Griffin, L., Hargis, P., \& Wilson, C. (2012). Social Class. In The new encyclopedia of Southern culture (Vol. 20). Chapel Hill, North Carolina: University of North Carolina Press.

Hennig-Thurau, T., Gwinner, K., Walsh, G., \& Gremler, D. (2004). Electronic word-of mouth -- what motivates consumers to articulate themselves on the internet? Journal of Interactive Marketing, 18(1), 38-52. doi:10.1002/dir.10073

Hill, W., Beatty, S., \& Walsh, G. (2013). A segmentation of adolescent online users and shoppers. Journal of Services Marketing, 27(5), 347-360. doi:10.1108/JSM-10-2011-0157

TI Outreach: Outbound Overview Outbound. (2013). Retrieved November 4, 2015, from http://travel.trade.gov/outreachpages/outbound.general_information.outbound_overview.html

U.S. TRAVEL ASSOCIATION. (2014, March 1). Retrieved November 4, 2015, from https://www.ustravel.org/sites/default/files/page/2009/09/US_Travel_AnswerSheet_March_2014.pdf

Wells, N., \& Fahey, M. (2015). Here's where everyone's going on vacation this summer. Retrieved November 9, 2015, from http://www.cnbc.com/2015/07/22/heres-where-everyones-going-on-vacation-this-summer.html 